Double Consciousness, Modernism, and Womanist Themes in Gwendolyn Brooks's "The Anniad"

\author{
A. Yemisi Jimoh
}

MELUS, Vol. 23, No. 3, Poetry and Poetics. (Autumn, 1998), pp. 167-186.

Stable URL:

http://links.jstor.org/sici?sici=0163-755X\%28199823\%2923\%3A3\%3C167\%3ADCMAWT\%3E2.0.CO\%3B2-E

MELUS is currently published by The Society for the Study of the Multi-Ethnic Literature of the United States (MELUS).

Your use of the JSTOR archive indicates your acceptance of JSTOR's Terms and Conditions of Use, available at http://www.jstor.org/about/terms.html. JSTOR's Terms and Conditions of Use provides, in part, that unless you have obtained prior permission, you may not download an entire issue of a journal or multiple copies of articles, and you may use content in the JSTOR archive only for your personal, non-commercial use.

Please contact the publisher regarding any further use of this work. Publisher contact information may be obtained at http://www.jstor.org/journals/melus.html.

Each copy of any part of a JSTOR transmission must contain the same copyright notice that appears on the screen or printed page of such transmission.

JSTOR is an independent not-for-profit organization dedicated to and preserving a digital archive of scholarly journals. For more information regarding JSTOR, please contact support@jstor.org. 


\title{
Double Consciousness, Modernism, and Womanist Themes in Gwendolyn Brooks's "The Anniad"
}

\author{
A. Yemisi Jimoh \\ University of Arkansas-Fayetteville
}

Double consciousness in African American literature is the phenomenon whereby a text simultaneously responds to two conflicting definitions of African American identity: a prevailing and debilitating European American definition as well as a more self-determined African American definition. This literary definition of double consciousness parallels Du Bois's description of psycho-philosophical double consciousness in The Souls of Black Folk. In Gwendolyn Brooks's "The Anniad" such double consciousness is perceptible in her poem's many subtle yet searing lines which reveal a prevailing astigmatism concerning race as well as gender in the United States. Gwendolyn Brooks's Janus-like poem-with its simultaneous focus on both gender and race-depicts some of the effects that an emerging media culture has had on standards of beauty among African American women, who often present a contrast to the definitions of beauty that are pervasive in the United States. Through this poet's use of double consciousness in "The Anniad," readers perceive that Brooks is acutely aware of the urban, black Chicago that shapes her aesthetic as well as the prevailing culture in the United States that could shape her success as a poet.

While my discussion does not contribute to the notion (nor do I insist on such regularity) that Brooks's content is incompatible with her form, I do find that the combined impetus of this poet's response to a segregated 1940s black Chicago as well as a segregated artistic and publishing milieu in the United States contributes to a tenuously poised, yet successfully meshed, content and form in "The Anniad." Both the content and the form strain against being silenced, in this poetic struggle against double consciousness. The form strains to contain the content which it must convey, as Brooks often subtly voices her sexual, gender, and racial topics in oblique images, allusions, and equivocal sexual word play that veil the plenitude that is barely 
contained in the margins of her form-the mock-epic.

Specific instances of Brooks's slant or indirect poetics include veiled allusions to writers whose artistry she appreciates, yet, whoat the time-were not regarded favorably or had lost value in the dominant cultural setting. Brooks opens "The Anniad" with a poet's nod to Paul Laurence Dunbar ${ }^{1}$ and his novel Sport of the God when she refers to Annie as a young girl "Whom the higher gods forgot, / Whom the lower gods berate." Other agnatic poetic echoes in "The Anniad" include lines from Langston Hughes and Countee Cullen, especially Brooks's apt image of black women in relation to their hair: "Then emotionally aware / Of the black and boisterous hair, / Taming all that anger down." Hughes presents a similar idea concerning black hair in his 1947 poem "Trumpet Player": "Has his head of vibrant hair / Tamed down" (Hughes 338). This image also occurs in Cullen's 1925 poem "Heritage": "Crowned with dark rebellious hair" (Cullen 247). In all three poets the idea of black people's hair collects images of "rebellion," and in the later poems by Hughes and Brooks this sense of revolt is "tamed." In both male poets, however, the emotional angst about hair that angers Annie does not exist for Hughes's trumpet player and Cullen's Jesus. These poets, in fact bring positive connotations to their references to hair, connotations which are not present for Brooks's Annie. This character's negative perception of hair, however, along with other gender-limiting issues are subtly critiqued in this poem.

In terms of her poetic style as well as in her uses of irony as a means through which she presents resistance to traditional gender roles, Brooks suggests enatic ${ }^{2}$ poetic echoes of Emily Dickinson's technique. Dickinson's poetic includes images of the secreted or concealed female poet, transformations of traditional form, punctuation, and line rhythms, and her depiction of male-female relations in-often ironic-divine or royal terms. This last stylistic quality is particularly apparent in lines from "The Anniad" such as "No dominion is defied" (100) as well as in Brooks's use of words and phrases such as diadem, sovereign, godhead, celestial, devotee, "nun of crimson ruses" (101) and other terms which recall Dickinson's uses of noble and heaven-focused language in her poems: "None suspect me of the crown, / For I wear the 'Thorns' til Sunset- / Then-My diadem put on"; (704-05) or "And now we roam in Sovereign Woods"; (369) as well as "Title divine-is mine!... / Royal-all but the Crown!" (487). Also, in terms of technique, Brooks illustrates Annie's sovereignty over a dissipated tan man in Dickinsonian fashion with unusual uses of uppercase letters in "Slide a bone beneath Her head, / Kiss Her eyes so rash and red." ${ }^{3}$ Finally, Dickinson's intriguing funeral poem, 
"I felt a funeral, in my Brain" (128), seems to resonate in the section of "The Anniad" in which Brooks presents tan man's funeral: "In the indignant dark there ride / Roughnesses and spiny things... / Cyclone concentration reels. / Harried sods dilate, divide, / Suck her sorrowfully inside" (109). Brooks suggests that Annie-while at tan man's funeral-feels a burial in her brain, her own mental or psychic live burial - which, of course is quite different from the metaphysical mood that Dickinson establishes in her poem.

Brooks's style and form in this poem indicate her ability to conform to dominant ideas about art-ideas which she illustrates with concepts, experiences, and critiques that resonate from the poem as a marginalized black female voice in tense relations with the dominant culture. Gloria Hull in "A Note on the Poetic Technique of Gwendolyn Brooks" characterizes this poet's style in the following terms: "quaint and unusual diction," "imperative tone," "verbal economy," "slyly satirical humor," "quaint colloquial tone" (281-84). In "The Anniad," then, this poet's Janus-like and double conscious responses to artistic hegemony add to her themes of race and gender, and this results in her artistic rendering of Gloria Wade-Gayles's term "triple jeopardy," (218) which refers to the race, gender, and artistic restrictions that African American women writers encounter. Brooks's double-looking themes of race and gender in "The Anniad" portray a black woman's unsuccessful quest to make an image of herself that she can position comfortably within her world-a world which seeks to delimit her in both gendered and racial ways.

Brooks's setting is a post World War II America, in which the war contributes to Annie Allen's defeat, but the effect of the war on Annie's life is not the major, or at least not the only, theme of the poem. Brooks as a "Double-conscious sister in the veil" (Harper ix) expresses her major theme- the injurious effects of the cultural hegemony of the dominant society in the United States on marginal groups such as black people and women-beneath a safe tale which speaks of the effects of the havoc inflicted on the women to whom the World War II soldiers returned. In this poem Brooks employs images of devastation that depict Annie Allen's debilitating inability to achieve selfconsciousness as a black woman-neither through art nor through domesticity as she perceives it. Brooks's own "mastery of form" and her elusive critiques and comments on it, as well as the events in the poem which show Annie Allen in constant contradiction with herself (because she is immersed in external definitions of gender roles and beauty) demonstrate the alienation of double consciousness in "The Anniad."

Houston Baker in Modernism and the Harlem Renaissance formulates 
the concepts "mastery of form" and "deformation of mastery." He designates "mastery of form" as a means through which black people established for themselves a literary voice. This voice, however revises the socially produced minstrel distortions of black people and transforms them into art, a "Promethian cultural appropriation" in Baker's terms (33). For him mastery's signal text is Booker T. Washington's Up From Slavery. In addition to "mastery of form" Baker further defines a "specifically Afro-American" discursive practice in the literary modernism of black writers in the United States with his correspondent concept-the "deformation of mastery" (xiv). Deformation unmasks the minstrel and reveals the folk-that is, the "territory within their own vale/veil." That territory is claimed boldly. Thus, Baker's deformation describes the process by which black writers claim and assert their own modern literary voice. (50-51). In Baker's formulation of deformation, Du Bois's definition of double consciousness in The Souls of Black Folk exemplifies Baker's strategy. Baker asserts that he does not view these terms in a determined opposition, yet "[a]ny instance of mastery of form is always suggestive of its correspondent and vice-versa" (99).

In "The Anniad" Brooks not only masters the dominant modernism she also employs mastery of form as she wears modernity's ventriloquist's mask-the 1940s mask of similarity that informs her "strateg[y] of attraction" (29). These strategies respond to the dominant culture's requirements that a black poet's voice must prove its worthiness by imitating an established modernist dominant model of art instead of demonstrating an established jim crow minstrel difference-which artistically conceals its coded subversion while ironically displaying its distorted difference. This modernist mastery of form-the ventriloquist's mask-is evident in Brooks's poetic technique and in her content. After, for instance, all of Annie's plots to gain love fail her, she turns to education and poetry: "Twists to Plato, Aeschylus, / Seneca and Mimnermus, / Pliny, Dionysius..." (106). Before, however, Brooks actually lists the subjects of Annie's classical education, the poet employs mastery of form and demonstrates her own depth of knowledge and positions herself within classical culture when she alludes to Plato in connection with Annie's crude imitation of paladins and their debauched parroting of her idealized notions of love while she is a prostitute (106). These men and this life for Annie are "copies of all her bright / Copies." This sort of "mastery" is required of Brooks in order for her to draw to her poetry the attention of the dominant culture.

Mastery, indeed, not only is true of Brooks's poetic strategies but also is true in her portrayal of Annie. In "The Anniad" Brooks depicts 
Annie's educational and literary success as "Pirouettes to pleasant shrill / Appoggiatura with a skill" (106). Annie here performs a properly refined dance in response to the comforting appreciation that her writing receives; she, apparently, does not have to jump jim crow if she renders a precise pirouette. Claudia Tate refers to this strategy as "literary hair-straightening" (Black Women 45). Additionally, Annie's music/poetry only ornaments the dominant cultural practices; there is not a place at the center of the dominant culture for Annie's talent, not even for her poetry that replicates dominant strategies. Indeed many of the African American poetic cultural qualities in "The Anniad" are so cryptic that a number of the possibly culture-specific lines in this poem suggest many plausible readings-which might easily distract readers away from the subtle, yet serious social critique imbedded in this poem. When, for instance, Brooks describes tan man's other women as "bad honey," (104) the poet reaps the benefits of the African American vernacular meaning of "bad" - which evokes connotations of the righteous outlaw whose rebellion has value from the perspective of the oppressed; thus, her or his outlaw or "bad" behavior is good. Hortense Spillers notes that in the vernacular "bad" has "appropriated its antonym" (229). This African American meaning for the word "bad" combines with its general English meaning and creates the possibility for plural implications in this poem. The same plurality exists in Brooks's uses of the word "passing" (104). Again, the African American vernacular meaning for "passing" adds both ironic and plural meanings to the lines in "The Anniad" in which Brooks uses it: "Minus passing-magistrate, / Minus passing-lofty light, / Minus passing-stars for night" (104). Here Brooks suggests the concept of passing as the act of presenting oneself as a member of the dominant group by denying or ignoring one's connections to an oppressed group; she also suggests the general meaning of passing as a momentary encounter-just passing through. ${ }^{4}$ For Brooks's Annie, it seems, innocence is lost. She no longer has in her life "passing"-either false or brief-(male) authority, artistic inspiration, and defining media images of beauty. These lines exemplify Brooks's coded vernacular in "The Anniad." As a poet she "conceal[s] and disguise[s]," yet respects her indigenous voice. Baker's deformation of mastery, then, is not present in "The Anniad," because of the muted black voice in this poem (Baker, Modernism 51).

W.E.B. Du Bois-Baker's noteworthy strategist of deformationdefines a basis for aspects of Brooks's poetic technique in his description of double consciousness. His use of this term seems most firmly based in Hegel's German idealism, which Du Bois revises and re-in- 
scribes and by which means he explains the American paradox of some of the enslaved, the formerly enslaved, and their descendants in the United States. Du Bois raises the issue of a particularly African American consciousness and he situates the notion of this consciousness within the psycho-philosophical intellectual knowledge with which he was familiar: "One ever feels his two-ness,-an American, a Negro: two souls, two thoughts, two unreconciled strivings; two warring ideals in one dark body, whose dogged strength alone keeps it from being torn asunder"(8-9).

According to Dickson Bruce, the concept of a double soul or consciousness is found not only in Du Bois but also in literary texts such as Emerson's 1843 “The Transcendentalist," Goethe's Faust, Whittier's "Among the Hills," and George Eliot's "The Lifted Veil" (300). Bruce's discussion of Du Bois and double consciousness emphasizes the influence of Du Bois's Harvard professor William James. This influence, however, seems less viable than the effects of strong Hegelian inspiration acting in concert with a rapidly industrializing and fragmentary modern society - which produced a heightened sense of alienation in people-as well as with Du Bois's sense of the disjointed and disconnected ante-bellum lives of black people in the United States.

In William James's The Principles of Psychology, his descriptions of "double or alternating personality" include a spontaneous onset of memory lapses during which time the person engages in behavior which s/ he attributes to an alternate personality of which no one else is familiar-including the original personality of the individual who is experiencing double consciousness (379). James's diagnosis of alternating personality, though, has become the standard way to discuss Du Bois's concept. James states that secondary personalities "are always abnormal and result from the splitting of what ought to be a single complete self into two parts, of which one lurks in the background whilst the other appears on the surface as the only self the man or woman has" (227). This schizoid effect of alternate personality does not correspond with Du Bois's double consciousness. In W.E.B Du Bois: Biography of a Race, David Levering Lewis also questions "to what extent, if at all, the insights of James's Principles of Psychology were the source of Du Bois's own special insights into what he would describe as the double nature of African-American psyche" (96). Lewis, however, continues to discuss Du Bois's concept as if it were a Jamesian schizophrenic secondary consciousness lurking in the background. Lewis refers to double consciousness as "psychic subordination" that has the potential to become an asset when it no longer is an African American image of self "reflected from a white 
surface" (281). This reading of Du Bois's double consciousness has persisted over time and resulted in a number of counter-statements such as those in Gerald Early's collection of essays Lure and Loathing: Essays on Race, Identity, and the Ambivalence of Assimilation.

Arnold Rampersad in his 1976 autobiography The Art and Imagination of W.E.B. Du Bois presents another perspective on Du Bois's reconceptualization of double consciousness. Rampersad discusses the distinctly parallel qualities of the "two warring ideals" that exist in an "American world" (8 [emphasis added]) that "Yields... [African Americans] no true self-consciousness." For Rampersad, Souls "affirms...[Du Bois's] faith in the strength of the African soul, against which that other powerful soul implanted by the white world wages constant war" (88). Gerald Early also recognizes the solidity of both poles of Du Bois's "two souls" and the error in too closely associating Du Bois's concept with James's. Early points out that with Du Boisian double consciousness people "consciously [know] the temptations of both" sides of their two souls, and they know "that both exist" (xxi). Du Bois was a student of and clearly influenced by William James, yet $\mathrm{Du}$ Bois also was a student at the University of Berlin when a major "Hegelian revival" took place (Adell 12).

In her book Double-Consciousness/Double Bind, Sandra Adell examines Du Boisian double consciousness as a Hegelian "consciousness containing a contradiction within itself" (18). Her position is that the major influence on Du Bois's concept are two forms of double consciousness described in Hegel's Phenomenology of Spirit. Hegel's philosophy of the formation of consciousness posits a self-consciousness that arises from a dialectic (within a triadic process) by which one becomes aware that one is separate from and differs from an/other. As a result of the tension and the reciprocal influence resulting from the interaction between each consciousness, both move beyond mere recognition of an other to a more developed consciousness than they previously had. Hegelian consciousness, then, is not developed ex $n i-$ hilo. This process necessarily makes the initial formation of self-consciousness double, and any growth in consciousness, then, proceeds through the Hegelian triadic process. When, however, an other ("a being") does not provide a reciprocal acknowledgment of otherness-as in the master-slave relationship - the process of developing self-consciousness is impeded; thus, it actually is double consciousness, according to Adell, that Du Bois describes as being denied to black people-because for Hegel "consciousness, if it exists at all, is always double consciousness" (19).

A second form of Hegelian double consciousness that one can draw from Du Bois's term is the self-contradictory or in Hegelian 
terms the "unhappy consciousness." One way that this self division occurs is that an individual never receives any external acknowledgment of his or her selfhood, which Hegel's absolute idealism requires-the knowledge that one is not a cipher in the larger world. In the case of an "unhappy consciousness," an individual a compensating internal or self division, instead of establishing selfhood in tension with an other/different self. Internal division results in a "false self" as well as a "true self." This true self is identified with perfection while the false self is a distortion created out of one's lack of contrast with an external other (Copleston 185). It is on this point that I will make my final comments on the operations of double consciousness.

Jamesian readings of Du Bois's double consciousness often result in comments such as the following made by sociologist C. Eric Lincoln in his essay "The Du Bosian Dubiety and the American Dilemma: Two Levels of Lure and Loathing"; for him, double consciousness "implies self hatred." Because of ambiguous assertions in Du Bois's description of double consciousness, his term has produced this assessment in literary analyzes as well as by other scholars. Lincoln says, however, that "[p]eople do not ordinarily hate themselves.... Self loathing is a counter function to survival and to the will to survive." Hatred of one's group, according to Lincoln, "originates outside the group and is learned" (198). Yet, when one indeed reads closely Du Bois's description of double consciousness with Hegelian concepts in mind, this process of selfhood-that Du Bois posits-consists in two internal conflicting definitions of consciousness, a false or debilitating consciousness and a self-determined true consciousness-thus, Hegel's unhappy consciousness. Du Bois's description also suggests the lack of reciprocal acknowledgment of selfhood that precedes an unhappy consciousness. Du Bois is not specific, however, on the issue of which side of the two souls engages in "always looking at one's self through the eyes of others." I must conclude that it is in the false consciousness that this perception exists; this is a consciousness derived from an "American world" in which we find distorted images of black people that allow this world to refuse to acknowledge another self when it is in a black body.

My position on Du Boisian double consciousness is based in the evidence of Du Bois's Hegelian background and in the comments that precede his brief discussion of double consciousness. These comments refer, favorably, I believe, to folk beliefs that connect black people to root/spirit-knowledge or Du Bois's African American version of the absolute: "seventh son" of the seventh son-a folk reference to a person who is born lucky or with spiritual insight; being born with a "veil" (the membrane of the birth sac covering one's face)-also a 
folk sign of deep spiritual insight; and being "gifted with second sight" (8; emphasis added). ${ }^{5}$

Readers of "The Anniad," need not agree with Hegel's absolute idealism in order to understand Du Bois's appropriation of it and Brooks's execution of it in her poem. One also need not conclude, as Thomas Holt does, that African Americans "should celebrate" double consciousness as the "source of 'second-sight,'" nor need one agree that it is self hate. Clearly, though, Du Boisian double consciousness is the type of doubled awareness of self, the double consciousness, with which Brooks shapes the poetic techniques in "The Anniad."

In form Brooks's "The Anniad" reflects her discovery of the literary Modernism of the United States. Her first exposure to the mainstream writers that shaped her era came from James Weldon Johnson who, after reading some poems a youthful Brooks sent him, suggested she "study carefully the works of the best modern poets-not to imitate them, but to help cultivate the highest possible standard of self-criticism" (qtd. in Mootry and Smith 166-67). Consequently, Brooks expanded her reading in Dunbar, Hughes, Dickinson, Milton, Shakespeare, Donne, and Spenser with Frost, Eliot, Cummings and Pound. Years later, in 1941, Brooks's poetry was influenced by Inez Stark, who had been a reader for the important national magazine Poetry. Stark encouraged Brooks's Modernism; her criticism influenced Brooks to strip her poetry to the bare essentials: "be careful not to list the obvious things.... Use them only to illustrate boredom and inanity." She further advised Brooks to cultivate a highly compressed style in which words merely suggest meanings or images and in which time and place are disrupted. Commenting on one of Brooks's poems, Stark says, "[d]ig at this until you have us see all the skeleton and no fat" (qtd. in Mootry and Smith 167). Such contracted, and seemingly impervious, poetry, lacking deictic aspects, results in Brooks's perfecting the style that shaped her own poetic practice. Many of these qualities-except imperviousness-persist in her poetry today. Still, "The Anniad" is far less perplexing than Eliot's landmark modernist poem The Wasteland.

Of additional interest, in terms of compression in "The Anniad," is the compression of form in this poem. Appearing to take seriously Eliot's advice concerning a poet's relationship to the past as defined in "Tradition and the Individual Talent," Brooks recalls the epic form in order to serve her modern poetic ends, and she depicts her times, not necessarily her unique self in this poem. Also, in light of the traditional function of an epic as a long verse narrative that in some way helps to shape a society or to form a nation, Brooks's choice of the 
epic form is fitting; the traditional breadth of such a poem, however, would fatigue the appreciation of many of this poet's contemporaries as well as today's readers of poetry. Thus, Brooks compresses her mock-epic into forty-three septets of terse, allusive, and compressed poetry. Perhaps, though, Brooks's use of language in "The Anniad" goes a bit beyond Eliot's concept of being immersed in the traditions and literature of the past. The language in this poem is often archaic and Latinate-though perhaps a reflection of the high reaching language of the epic tradition. Such language, however, is more reminiscent of the English Renaissance than the American modernism of Williams, Moore, and Stevens-which emphasized the use of colloquial language - or of international modernism which occasionally disrupted a colloquial voice with words or phrases from Provencal, Latin, or Greek - as in the case of Eliot and Pound.

In "The Anniad" Brooks uses archaic English phrases such as "doughty meanings die" (103), "helmets final doff" (103), and "bejeweled diadem" (102) as well as Latinate and French words such as "paradisiacal" (105) and "bijouterie" (106). It is in such language that Brooks conveys her satire in this mock-epic. Clearly, though, the poet's use of what seems to be over-reaching erudition in the Anniad evinces her "mastery of form." Baker states that mastery of form is a literary strategy associated with Harlem Renaissance writers' (Brooks's direct literary ancestors) expression of Modernism. Baker defines this strategy as a mocking minstrel perfection of European American literary models. Through mastery of form, African American writers create a space for their own voices. This space, simultaneously critiques European American models and speaks for itself ( $\mathrm{Po}$ etics 15-24). For Brooks-at the time a young, black, female poetmastery of form in "The Anniad" is satirical, thus a critique. ${ }^{7}$ She presents a dazzling display of formal technique, which was required by the dominant society; in light, however, of Annie's defeat at the end of the poem, Brooks indicates that this dazzling art is false, gilded. This technique does not nurture Annie's aesthetic. To this end, in an interview with Hull and Gallagher, Brooks comments that Annie Allen is a book in which she did not "always have the best motives. I wanted to prove that I could write well" (32).

Brooks, further, demonstrates both epic tradition as well as the allusiveness of modernist poetry in her title, which plays on both Homer's and Virgil's titles. ${ }^{8}$ Just as Virgil gives his Latin epic The Aeneid a Greek title, thereby situating his Latin poem within the epic tradition of his predecessor from the dominant culture-the Greek Homer-Brooks's title accomplishes the same end by recalling seminal Greek and Latin poetic texts from the ancient Western tradition 
which shapes the dominant culture in the United States. Brooks further writes her poem into the branch of ancient Greek and Latin tradition that exists in the United States when she employs Virgilian purposes in her modernist poem. Brooks demonstrates the poetic seriousness, beauty, and complexity of a culture that has limited currency in the contemporary cultural milieu.

Another important aspect of an epic poem is its hero or central character. Again, in this instance Brooks's modernity updates, but does not mock, her central character. In fact, Annie Allen, the central figure in "The Anniad," is characteristic of what Arthur Davis identifies as the "unheroic" in the writing of Gwendolyn Brooks. Likewise, Claudia Tate finds that such characters not only appear in Brooks's work but also represent a particular type of character that is present in the texts of other African American women writers': Pecola in Morrison's The Bluest Eye, Eva in Gayl Jones's Eva's Man, and Beau Willie in Shange's For Colored Girls, for example (xxiv). Unheroic characters, suggests Tate, are worthy subjects in the writing of black women because they exemplify the unjustly defeated in whose fall others can locate and avoid qualities that are likely to bring similar defeat on them (xxiv). It is perhaps the unheroic in Brooks's Annie Allen that prompts D.H. Melhem's perceptive assertion that "The Anniad" "is a mock heroic, more compassionate than critical or satirical" (62).

Again, if "The Anniad" is in any way satirical, that satire is conveyed through Brooks's mocking use of high reaching language and is not directed toward the poet's central character. When, for instance, Brooks refers to Annie's "lofty light," she uses this language in order to demonstrate the sharp contrast between Annie's real life circumstances, and her confused perceptions (104). Annie, then, is the object of an empathetic critique (not satire) because she accepts, without question, the very social ideas that destroy her. Thus, Brooks has chosen the words of this poem so that they resonate a plenitude of ideas associated with her motifs of idealized notions of love, the myth of Americanism, and narrow concepts of beauty as well as other delimiting notions of the female. This poem illustrates the failure of these notions in the lives of Annie and tan man.

In "The Anniad" Brooks, clearly, satirizes the society that produces Annie. To that end, Brooks uses the language in her poem as well as Annie's dainty attitude as metaphors that signal artifice; both are gaudy ornaments covering the beauty and simplicity of the objects on which they have been placed: Annie and Brooks's poem. Brooks levels a subtle yet biting criticism at such ornamentation and at a society that encourages such artifice in its art and for its women. Lan- 
guage in this poem-when viewed as a satirical device-is purposely overdone to provide a mocking contrast in a poem written-during the post-war boom era in the United States-about a woman who is "physical and underfed" (99) and whose environment is described with oxymoronic contrasts such as "Pretty tatters blue and red, I Buxom berries beyond rot" (99; emphasis added). Additionally, the demure and dainty role Annie accepts at the beginning of the poem is exposed at the end as a farce, when Annie has become "tweaked and twenty-four" and her "soft aesthetic is looted lean" (108). Annie, however, is not the object of Brooks's mocking; it is the ornament that is mocked because of its devastating effects.

The modernist, skeletal structure of "The Anniad" and its epic form confirm Brooks's immersion in the prevailing culture that sets poetic standards. Brooks recalls the epic tradition through her use of brisk lines, repetitions, and an episodic or imagistic structure instead of a smoothly connecting narrative. These aspects of the poem evoke the qualities of oral transmission even though "The Anniad" is a literary epic. Also, as in other epics, this work begins in medias res, has magical forces that aid the central character, has a serious tone and exalted diction, as well as battles and boasts. Yet, according to Melham, Brooks forges a precise equilibrium when she encounters the challenging contrast that exists between "strict compression" of modernist poetry and the capacious qualities of the epic tradition (Melhem 63). Brooks's themes in combination with her modernist diction, allusiveness, and lack of deictic aspects in "The Anniad" make it a double-voiced modernist poem. On the whole, then, Brooks combines modernist poetics, epic tradition, as well as black and womanist themes in "The Anniad."

Brooks also probes gender relations, which often are reinforced in the dominant media as well as in social discourse; and she critiques the prescriptive nature of those relations. One of the major gendered themes in "The Anniad" is black women-represented by Annie Allen - who are trapped in the beauty and gender role fictions of the dominant society in the United States. Mary Helen Washington defines this motif as the "intimidation of color," which she finds is a consistent issue in many African American women writers' works (xiv). Brooks also depicts Annie as unheroic, which in this instance, is this poet's transformation of epic heroism. Brooks critically employs both the unheroic as well as the "intimidation of color" in ways that exemplify her covert poetic move toward establishing a black female consciousness that is constructed as more self-defined than double. Through Brooks's themes in "The Anniad," she demonstrates that a black woman's belief in the dominant beauty and gender role fictions 
will cause her to suffer immensely-more than the typical white woman-because the image of womanhood and physical beauty that is projected by the dominant culture is unreal and almost unattainable (without tremendous physical alterations) for most black women. Brooks enjoins her readers to

Think of thaumaturgic lass

Looking in her looking glass

At the unembroidered brown;

Printing bastard roses there;

Then emotionally aware

Of the black and boisterous hair,

Taming all that anger down (100).

In this stanza Annie prepares herself to meet with "tan man." The blush she uses on her clear brown skin is an obvious aberration since her cheeks in no way lack color. Thus, the black-not blond-and "boisterous" - not straight-hair becomes an obvious symbol of her pretense as well as a symbol of the falsity of the prevailing beauty fictions. Despite the "bastard roses"9 (100) Annie prints on her cheeks and the "taming" (100) to which she subjects her hair, she is still notably different from the fictitious image she emulates. Annie's misdirected conjuration is contrasted in this poem by the magic worked from the root or from within by the other women that tan man chooses.

Some of tan man's choices in women are dangerous; they will be the death of him. Unlike Annie, though, these other women are vibrant and alive within themselves. Perhaps more than anything else, tan man rejects the weak, spiritless, feigned attitude that Annie adopts. Yet, there is no doubt that he also doesn't value her chocolate skin-color. Tan man's post-war women are "gold," "maple," and an indeterminate (probably Filipino) "gypsy." These women not only are lighter shades of brown than Annie but also are in possession of their own voices as well as their own methods of conjuration. The woman with the gold skin is a "shriek." She voices strongly stated opinions, and enchants tan man so that he is blind to her imperfections: "Hissing gauzes in her gaze, / Coiling oil upon her ways. His "maple banshee" also is associated with spirit-work or preternatural knowledge, which she conveys through the sweet wailing of her powerful voice. Tan man, ostensibly, ignores her message or is oblivious to its importance. The final woman among tan man's "violent vinaigrettes" or "bad honey[s]" is his "gypsy moan." Her voice may not be articulated as clearly as the voices of the other women; her 
eyes may not be as open to the spirit-world as the eyes of the other women, or perhaps her eyes are shaped differently; but she still is associated with other-worldly-gypsy-knowledge and a voice of her own-instead of a received voice that she takes from an external source (104). These women speak for themselves; they are saucy flavoring, that enliven Annie's nearly wasted tan man.

Annie, nevertheless, undercuts her own worth in her relationship with tan man. "Sweet and chocolate" Annie is uncomfortable with the demure and coy attitude she believes society prescribes for women, but she decides to adopt this attitude anyway. Realistically, though, Annie is not an "icy jewel" (105) for tan man's "bejeweled diadem" (8). She is a woman who can "remark his feathers off" (108), but she feels compelled to tame herself, in the same way she tames the tumult of her hair. To complement her adopted attitude, Annie fantasizes about a man who is as unreal as the woman into which she attempts to make herself. She hopes tan man will be her paladin. Such a role for him or, in fact, any man is unrealistic. Yet, Annie's romantic perceptions of the world do not allow her to see tan man in the context of the society in which they live. Through her narrator Brooks demonstrates that for Annie and tan man the myth of the United States that is perpetuated in the dominant society is as fictitious for them as Annie's idealized notions of love are for her.

In the opening stanzas of "The Anniad," Brooks employs oblique allusions that point to post-war patriotism as part of the myth of Americanism: freedom, democracy, opportunity. This myth is juxtaposed against Annie's idealized notions of love and is depicted as equally fantasy-laden. Brooks opens her second stanza with a double-focused line that points to Annie's illusions about romance in the first stanza and at the same time moves readers forward to the illusory splendor of a segregated United States: "What is ever and is not." Brooks uses oxymoronic contrasts of beauty and decay to describe Annie and to describe her relationship to the beacon of democracy in which she lives: "Pretty tatters blue and red." This images suggest a ragged flag in which Annie is wrapped or a dress in similar disrepair. The next two lines of "The Anniad" continue to develop this image. The fruited plains are dried-up and spoiled: "Buxom berries beyond rot." The blue skies are cloudy and the bright stars are not at their fullest brilliance. All of the patriotic images which refer to the United States as well as patriotic songs such as "America the Beautiful" are "Fairy-sweet of old guitars / Littering the little head": old music ${ }^{10}$ altered by pleasing illusions of change (99).

Tan man's relation to the promises of the United States is similarly exposed as false. Brooks depicts the war as "Surrealist and cynical," a 
nightmare of grotesque slaughter which-among black people-results in realistic disbelief in the sincerity of the promises that things will improve after the war (102). As a soldier, tan man's American dream of freedom is crushed. After the war, for example, the disappointment tan man experiences upon his return home causes him to see himself and Annie differently: "With his helmet's final doff / Soldier lifts his power off" (103). Tan man can no longer live the fantasy of freedom and democracy, for which he fought in the war; and he can no longer pretend he can live according to the received concept of reality (the American Dream) in the United States either. This knowledge leads tan man not only into rejecting Annie but also into debasing himself. The patriotic fiction is a ruin for Annie and for tan man. Tan man does not find truly viable options to the false promises of the United States, so he is destroyed. And Annie does not abandon her equally destructive adherence to gender role and beauty fictions which obliterate her mind.

Brooks suffuses this poem with themes such as gender role and beauty fictions, Washington's "intimidation of color," Hull and her co-editors" spiritual activities of "root working, conjure, and midwifery," and Walker's woman as suppressed artist. This poet's elemental concern with gender-focused imagery that scholars now find collected around images of women, particularly black women's portrayal of black females in literature, illustrates her use of womanist social and literary concerns in "The Anniad." Hence, three motifsblack self-definition, the constrained artist, and womanist concernsconcatenate in this poem to allow readers a glimpse of what Gloria Wade-Gayles terms "the narrow space of race and the dark enclosure of sex" (21).

Brooks's "The Anniad" is the tale of Annie Allen, a plain brown "sweet and chocolate" woman with a plain name who lives in a fantasy world of "cinema mirage" (104) in which her desires over-reach reality. Her world is dream-like, a world of "fancying on the featherbed." Annie rests her head/thoughts on insubstantial dreams instead of the thoughts that Brooks will evoke in readers-thoughts for which she requests inspiration in her invocation of the muse. ${ }^{11}$ Annie is described as a woman "Whom the higher gods forgot, / Whom the lower gods berate" (99). Brooks begins her poem by informing readers that this "chocolate" woman is forgotten by whites ("higher gods") because she is a black woman and, because of her dark skin, is berated by ("lower gods") blacks. ${ }^{12}$ This color motif in "The Anniad" indicates that the poem reflects both interracial and intraracial "exile rhythms," or the "desire for at-homeness in the universe of...[one's] native land" (Kent 84). Equally important is Brooks's subtle sugges- 
tion that Annie consciously and against her own disposition acquiesces in a socially imposed female silencing. Annie shows, for example, "gilt humility" (100) after losing her virginity to tan man. She pretends to swoon and feigns being overwhelmed by tan man's sexual prowess, so instead of expressing the "hot theopathy" (100) she feels during their encounter, she displays a "dusted demi-gloom," which is apparently consistent with the attitude that "respectable" women have toward sex.

Later, however, tan man returns from the war dismayed to find that he is still just another black man in the United States. He must now face "this white and greater chess" (103) of racism. Such a situation "baffles tan man" (103). He didn't expect to continue his overseas war games (fighting for freedom) when he returned. The benefits of being a World War II veteran, he learns, will not give him an equal position in society; he decides that "woman fits for recompense" (104). As for Annie Allen, tan man says, "Not that woman! (Not that room! / Not that dusted demi-gloom!)" (104). So the respectable Annie who, when tan man went to war had retreated to a "...lowly room. / Which she makes a chapel of. / Where she genuflects to love" (101) is rejected by a newly aware and bitter "tan man." He chooses "Nothing limpid, nothing meek. / But a gorgeous and gold shriek, a "maple banshee," and a "sleek slit-eyed gypsy moan" (21-22). Clearly tan man is self destructive; he, thus, prefers each "random bacchanalian lass / That his random passion has" (104) to Annie's feigned ornaments of coyness. Annie's “...paladin / Which no woman ever had, / Paradisiacal and sad " (99) is an example of her idealized and unreal concept of male and female gender roles. She, however, does get tan man, whom she loves and perhaps feels fortunate to have, but she loses him after his return from the war leaves him infirm and disillusioned.

Now that Annie's "set excess" (101) or unreal expectations have come tumbling down, Brooks shows that over time-through all of the seasons-and without tan man Annie attempts to adjust her perceptions-even though she desires palliation from tan man. Each season brings Annie a different disposition as well as varied insights into her situation. And perhaps each season also represents a different type of man. Annie's emotions in winter are frozen "icy jewels"; she experiences emotional stasis as she "Seeks for solaces in snow"perhaps assuages tan man's rejection of her by taking a white lover. Brooks also seems to suggest that Annie's sadness, "Half-blue shadows," is not alleviated by the money that this lover provides: "blue and silver rime." His gestures, in fact, are cold and only freeze her emotions to a harder "crust." ${ }^{13}$ Conversely, spring for Annie is pas- 
toral, sprite-filled, and airy: "fluting spring," "Bubbles apple-green," "Pucks and cupids." In this more light-hearted season of her disposition Annie "Seeks for solaces in green," or consolation in younger men. Annie's "Hyacinthine devils" - in their association with conjure-parallel tan man's "Hissing" and "coiling" woman, his "banshee," as well as his "gypsy moan." When, however, summer arrives Annie has become more careful in her selection process, so she "Runs to summer gourmet fare." She finds that her love environment becomes "inert," and "summer hoots at solitaire." Autumn, however, seems to suit her most because "All gone papery and brown"; here Brooks indicates the thinness of Annie's character through her image of the papery, brown leaves. And Brooks's line "[a]ll's a falling falling down" evokes Annie's depressed emotional condition. Brooks may also suggest in this stanza that when Annie visits the park she is there among other lonely women on "respectable walks" (104-05). With this in mind and in her depressed mood, Annie desperately cries out for love from anyone saying, "I am bedecked with love!' / 'I am philanthropist!' / 'Take such rubies as ye list.'" When Annie fails to get adoration from the preceding actions, she attempts to "find kisses pressed in books." Books and brief fame are, however, a "thin Hurrah" (106). So Annie wraps her fantasies around her children until a "Preshrunk and droll prodigal" tan man (107) returns. This time when a seriously dissipated tan man leaves, it is through death. Brooks depicts this last disappointment in romantic love as the catalyst that pushes Annie further into her dream world which "Suck[s] her sorrowfully inside" (109). Annie does not survive psychologically; this is the case even though, after tan man returns-and before his death-she has acquired enough self-respect to advise him that he has little to offer her because his age-"rust" - and infirmity"cough" — can "scarcely re-launch / That is dolesome and is dying"; this refers to tan man himself as well as their relationship (108). Nevertheless, after tan man is gone, Annie thinks back and remembers that she was no competition in the battles with his mistresses for his love. She realizes that even now the telephone's ring "hoists her stomach to the air," while surely his mistress "Who is starch or [the one] who is stone / Washes coffee-cup and hair, / Sweeps, determines what to wear" to tan man's funeral. Unable to bear her life after her fantasy fails, Annie retreats into liquor and the "minutes of memory" (109).

From the apartment and neighborhood bar of one conjure woman whose "culprit magics fade" (107), Gwendolyn Brooks in "The Anni$\mathrm{ad}^{\prime \prime}$ deftly examines the insidious nature of prescribed beauty standards, the destruction racial prejudice engenders, and the emptiness 
in the "Pirouettes to pleasant shrill" (106) of constrained women artists who write against the grain of the dominant culture. Brooks's poem is a subtle critique presented through the poetry of indirection that results from a diminishing of double consciousness among black people who are beginning to reject the internalized negative definitions of themselves that evolve from the mainstream culture in the United States. As an African American, female poet in the 1940s, for Brooks to write a modernist mock-epic poem that ostensibly addresses the issue of post-war disappointment in love was clearly more acceptable than a direct comment on intraracial as well as interracial discrimination or on the cultural hegemony of the dominant society in the United States. Despite her constraints, Brooks's multiple themes emerge through the palimpsest of "The Anniad." In this poem Brooks examines and critiques the hegemony of the dominant society, and at the same time she critiques women's facile acceptance of mainstream notions about beauty and gender-roles. Brooks also validates the experiences of African American women who find themselves overwhelmed by these fictions, yet she subtly suggests that they abandon them.

\section{Notes}

1. See Mootry and Smith. Brooks's mother Keziah admired Dunbar's poetry and wanted her daughter to become the "Lady Dunbar" (8).

2. Ellison responds to Irving Howe's "Black Boys and Native Sons" in a series of essays titled "The World and the Jug" and "A Rejoinder," both re-printed under the first title in Shadow and Act. Ellison, in "The World and the Jug" explains his literary heritage as consisting in literary "relatives"-Langston Hughes and Richard Wright-and literary ancestors-Ernest Hemingway, T. S. Eliot, etc (139-140). I make a similar distinction between Brooks and the Harlem Renaissance writers, Hughes and Cullen and Brooks and Emily Dickinson.

3. See Emily Dickinson's \# 306 for a poem on a similar topic; another interesting note in terms of Brooks's use of uppercase and lowercase letters is her consistent lack specific uses of Annie's name in this poem and her use of lowercase letters in reference to tan man. Both practices seem to inscribe in this poem the relative position each character holds in relation to the dominant society in the United States.

4. See a similar discussion in Stanford (301n).

5. Paul Gilroy in his book The Black Atlantic also positions Du Bois's double consciousness within the context of his experiences at the University of Berlin and in the context of German idealism. Gilroy, in response to Cornel West's observations on double consciousness in West's The American Evasion of Philosophy, also focuses on Du Bois's references to profound vision. I, however, in contrast to Gilroy locate Du Bois's references to sight in The Souls within an African American cultural construct which has shaped and is shaped by Du Bois's revision of Hegel. 
6. On double consciousness in Brooks see also Norris B. Clark (87) and Houston Baker $(21,28)$ both in Mootry and Smith.

7. See George Kent's discussion of high-reaching language in African American texts. For Kent such language allows the poet to demonstrate a high level of intellectual and creative virtuosity based in European-American poetic traditions. Such poetic overreaching is an expression of "exile rhythms," or poetic expressions of "a people experiencing resistance to their desire for at-homeness in the universe of their native land, and seeking firm establishment of it [at-homeness]" (84).

8. Brooks says that she had in mind Homer's Iliad - see Spillers "Gwendolyn the Terrible" (226); see Tate's "Anger so Flat: Gwendolyn Brooks's Annie Allen". Tate discusses Brooks's title in relation to Homer; see also Stanford's "An Epic with a Difference." She discusses Brooks's title as an echo of Virgil's Aeneid.

9. Stanford associates Annie's makeup with artistry and beauty, instead of misdirected conjure as I do. This critic also associates Annie's "bastard roses" with an inappropriate romantic context to which Annie has no access (283) instead of the inappropriate beauty context that I discuss in this paper. (Of course, Annie's media exposure illustrates that she has had as much access as any other 1940s woman had to such fictions. Perhaps, though, she had fewer opportunities to act them out); see also Tate's "Anger So Flat." Tate reads "bastard roses" as a figure for "ill conceived daydreams." Tate also reads Annie's "boisterous hair" as a figure of the flattened "vitality of...Annie's internal life," yet she does not address the related issue of beauty fictions (148).

10. This may be a veiled allusion to integrated big band music which reshaped earlier blues / jazz and was often referred to as "sweet."

11. See Stanford for a different reading of Annie and the featherbed (289). On the muses I am thinking of possible echoes of Homer's invocation in the Odyssey which begins with an apostrophe, requesting that the muse inspire the poet with the story of the brilliant Odysseus and in the Iliad which begins with an apostrophe to the muse, requesting that she inspire him with the song of Achilles' anger; also in Virgil's Aeneid, the poet sings of war and men at war. Interestingly, Brooks does not request a story, song,or music from her muse. She requests thought, which at the time was rarely acknowledged as something which black people possessed.

12. See Davis's "The Black-and-Tan Motif in the Poetry of Gwendolyn Brooks."

13. Spillers also suggests that Brooks hints that Annie has a white lover in the "Anniad" (231).

\section{Works Cited}

Adell, Sandra. Double-Consciousness/Double Bind: Theoretical Issues in TwentiethCentury Black Literature. Urbana: U of Illinois P, 1994.

Baker, Houston A, Jr. Afro-American Poetics: Revisions of Harlem and the Black Aesthetic. Madison: U of Wisconsin P, 1988.

. Modernism and the Harlem Renaissance. Chicago: U of Chicago P, 1987.

Brooks, Gwendolyn. Blacks. Chicago: The David Company, 1987.

Copleston, Frederick. A History of Philosophy. Vol. 7. London: Search P, 1963.

Cullen, Countee. "Heritage." Harlem Renaissance Reader. Ed. David Levering Lewis.

New York: Viking, 1994. PS153.N5 p 67.

Davis, Arthur. "The Black and Tan Motif in the Poetry of Gwendolyn Brooks." CLAJ 
6 (1962): 90-97.

Early, Gerald. Lure and Loathing: Essays on Race, Identity, and the Ambivalence of Assimilation. New York: Allen Lane-Penguin, 1993.

Eliot, T. S. Selected Prose of T.S. Eliot. Ed. Frank Kermode. New York: Harcourt, 1975.

Ellison, Ralph. Shadow and Act. 1953. New York: Random House, 1964.

Gilroy, Paul. The Black Atlantic: Modernity and Double-Consciousness. Cambridge: Harvard, 1993.

Harper, Michael. "Madimba: Gwendolyn Brooks." A Life Distilled: Gwendolyn Brooks Her Poetry and Fiction. Eds. Maria K. Mootry and Gary Smith. Urbana: U of Illinois P, 1987.

Holt, Thomas C. "The Political Uses of Alienation: W. E. B. Du Bois on Politics, Race, and Culture, 1903-1940." American Quarterly 42 (1990): 301-23.

Hughes, Langston. "Trumpet Player." The Collected Poems of Langston Hughes. Ed. Arnold Rampersad and David Roessel. New York: Knopf, 1994.

Hull, Gloria. "A Note on the Poetic Technique of Gwendolyn Brooks." CLAJ 19 (1975): 280-85.

Hull, Gloria and Posey Gallagher. "Update on Part One: An Interview with Gwendolyn Brooks." 21 (1977): 19-40.

Hull, Gloria T., Patricia Bell Scott, and Barbara Smith, eds. All the Women Are White, All the Blacks Are Men, But Some of Us Are Brave: Black Women's Studies. Old Westbury, NY: Feminist P, 1982.

James, William. The Principles of Psychology. Vol. 6. New York: Dover, 1890.

Kent, George. "Aesthetic Value in the Poetry of Gwendolyn Brooks" Black American Literature and Humanism. Ed. Baxter R. Miller. Kentucky: UP Kentucky, 1981.

Melhem, D. H. Gwendolyn Brooks: Poetry and the Heroic Voice. Lexington: UP Kentucky, 1987.

Mootry, Maria and Gary Smith, eds. A Life Distilled: Gwendolyn Brooks, her Poetry and Fiction. Urbana: U of Illinois P, 1987.

Spillers, Hortense. "Gwendolyn the Terrible: Propositions on Eleven Poems." A Life Distilled: Gwendolyn Brooks, Her Poetry and Fiction. Ed. Maria Mootry and Gary Smith. Urbana: U of Illinois P, 1987. 223-35.

Stanford, Ann Folwell. "An Epic with a Difference: Sexual Politics in Gwendolyn Brooks's 'The Anniad.'” American Literature. 67 (1995): 283-301.

Tate, Claudia, ed. Black Women Writers at Work. New York: Continuum, 1983.

Tate, Claudia. "Anger So Flat: Gwendolyn Brooks's Annie Allen." A Life Distilled:

Gwendolyn Brooks, Her Poetry and Fiction. Eds. Maria Mootry and Gary Smith. Urbana: U of Illinois P, 1987. 140-52.

Wade-Gayles, Gloria. No Crystal Stair: Visions of Race and Sex in Black Women's Fiction. New York: Pilgrim, 1984.

Walker, Alice. In Search of Our Mothers' Gardens: Womanist Prose. San Diego: Harcourt, 1979.

Washington, Mary Helen, ed. Black-Eyed Susans: Classic Stories by and About Black Women. Garden City, NY: Anchor, 1975. 